\title{
Grain Size and Major Oxide Analyses of Selected Anthill Soils from Winneba Area, Ghana
}

\author{
George Mensah Tetteh, Julian Kuundaah Angwaasong Zuyeri \\ Department of Geological Engineering, University of Mines and Technology, Tarkwa, Ghana \\ Email: gmtetteh@umat.edu.gh
}

How to cite this paper: Tetteh, G.M. and Zuyeri, J.K.A. (2017) Grain Size and Major Oxide Analyses of Selected Anthill Soils from Winneba Area, Ghana. Journal of Geoscience and Environment Protection, 5, 264-274.

https://doi.org/10.4236/gep.2017.59018

Received: August 18, 2017

Accepted: September 23, 2017

Published: September 26, 2017

Copyright $\odot 2017$ by authors and Scientific Research Publishing Inc. This work is licensed under the Creative Commons Attribution International License (CC BY 4.0).

http://creativecommons.org/licenses/by/4.0/

\begin{abstract}
Termites build their habitat in the form of anthills or termitaria or termite mounds which are characterised by soil of clayey texture. This paper investigated the relative grain size from the base, middle and near the peak of three anthills located $20 \mathrm{~km}$ west of Winneba near the Apam-Winneba highway in Ghana and also correlated their elemental compositions. The results showed significant grain size gradation of soils which range from $<0.075 \mathrm{~mm}$ to $2 \mathrm{~mm}$ such that coarse grains occurred at the base while finer fractions were at higher parts of the anthills. Major oxides (wt. \%) showed that $\mathrm{SiO}_{2}(51.70$ 60.24) was positively correlated with total $\mathrm{FeO}(12.22-15.24), \mathrm{Al}_{2} \mathrm{O}_{3}(22.18$ 28.88), $\mathrm{MnO}(0.08-0.09)$, and $\mathrm{K}_{2} \mathrm{O}(0.4-0.61)$. However, as $\mathrm{K}_{2} \mathrm{O}$ decreased with height on anthill, $\mathrm{SiO}_{2}$, total $\mathrm{FeO}$ and $\mathrm{Al}_{2} \mathrm{O}_{3}$ increased. Probably soils used to construct these anthills were derived from different rock types and/or the termites were selective in the use of soils rich in silica or iron oxide.
\end{abstract}

\section{Keywords}

Termites, Anthill, Termitaria, Soil, Grain Size, Major Oxides

\section{Introduction}

Anthill (termitaria) is a habitat of termites constructed with soils of modified texture, increased content of organic matter, phosphorus $(\mathrm{P})$, nitrogen $(\mathrm{N})$, and potassium (K) due to biological activities of the ants [1] [2] [3]. According to Akinboboye and Ogunfayo [4], grain size distribution of silt and clay from different locations vary with different anthills but all show low plasticity. Anthill soil could be used in place of shale for the production of cement if it was well graded [4].

Anthills were used in geochemical mineral exploration by West [5] in the Leopard Mine of Zimbabwe where termites transported elements from depth to 
the surface for construction of termitaria. According to Affam and Arhin [6], the height of anthill or termite mound reflects the depth of burrowing. Thus the higher the anthill the deeper the depth burrowed by termites. According to Rao and Raju [7], where termite mounds occur in large numbers particularly in tropical areas with thick overburden, their efficacy as prospecting tool could be employed.

The study area is located at about $20 \mathrm{~km}$ west of Winneba junction in Gomoa East district, located in the south-eastern part of the Central Region of Ghana. The district experiences two rainfall seasons-the major rainy season is from March/April-June/July while the minor season is from September-November. The main dry season is from November to March and a minor one from mid-July to mid-August [8]. Mean annual rainfall currently ranges between $70 \mathrm{~mm}$ and $90 \mathrm{~mm}$ in the southern coastal belt and between $90 \mathrm{~mm}$ and $110 \mathrm{~mm}$ in the north-western semi-deciduous forest areas [8]. According to Anon. [8], the district has two main vegetation zones-the dry coastal savannah and the moist semi-deciduous forest. The coastal savannah consists of grassland with scattered patches of thicketsin the south-east.

The area of study is underlain by the Birimian Supergroup composed of metavolcanic rocks with isolated amphibolite due partly to contact metamorphism from granitoid intrusives; generally foliations dip at $5^{\circ}$ to $20^{\circ}$ towards the north-northwest (Figure 1) [9] [10].

\section{Materials and Methods}

Of the many anthills which occur on either side of the highway from Apam junction to Winneba junction in Ghana, three of them which were used for the study, were located at about $20 \mathrm{~km}$ west of Wnneba junction. Their positions were picked using GPS and sampled at the surface from three spot heights after their circumferences were measured at the base at $5 \mathrm{~cm}$ from the ground, middle, and at the top. To avoid contamination of samples, mount surfaces were cleaned by scrapping with a metal chisel, bagged and labelled. Samples from the field were dried in the open sun, coned and quartered to obtain a representative sample. A quarter of the sample was taken, weighed to $500 \mathrm{~g}$, soaked in water and passed through $0.075 \mathrm{~mm}$ sieve to separate the upper size (sand fraction) and under size (fine fraction). Grain size distribution for the sand fraction was obtained through sieving and under size dried and weighed. These analyses were done in the Geotechnical Laboratory of the University of Mines and Technology at Tarkwa in Ghana. Elemental composition was determined on two batches of samples by X-Ray fluorescence analysis at the Geological Survey Department (GSD) in Accra, Ghana.

At GSD, each sample with a labelled tag was put in a crucible, oven dried at a temperature of about 105 degrees Celsius for 20 minutes after which samples were removed and put into glass desiccators to prevent moisture entry whilst cooling. Then $4 \mathrm{~g}$ of each sample was then mixed with about $0.9 \mathrm{~g}$ of wax powder, 


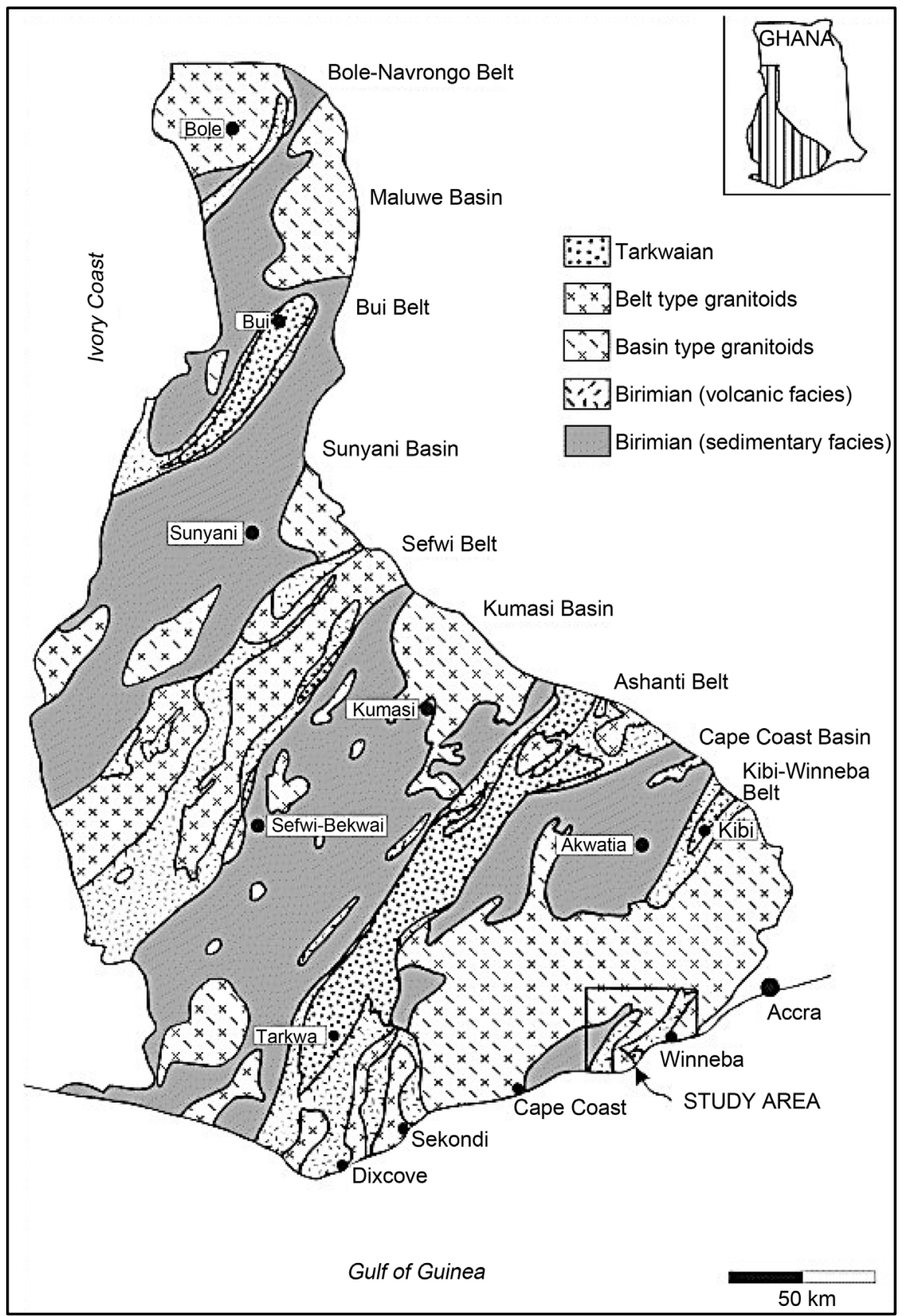

Figure 1. Map of SW Ghana showing the study area (modified after Leube et al. [10]).

homogenised by milling for about 5 minutes and then compressed under a load of 15 tonnes to obtain a $32 \mathrm{~mm}$ diameter pellet. X-ray florescence analysis was conducted using SPECTRO X-LAB 2000 multi element analyser to obtain major oxides (wt. \%) and trace elements (ppm).

\section{Results}

The land surface of the study area was gently undulating, occupied by poorly drained, dark olive brown clay or yellowish red silt clay with scarce iron oxide and manganese oxide nodules. Anthills used for the study were wider at the base 
(6.0 - $6.8 \mathrm{~m})$, reduced near the middle by about $1.0 \mathrm{~m}$ and smaller at the top by a third. These structures were up to $2 \mathrm{~m}$ high (Figure 2). Samples taken from anthills with contrasting colours (brown, brownish yellow and light brown) were coned and quartered to obtain a sample weight of about $500 \mathrm{~g}$ (Figure 3 and Figure 4 respectively). XRF analyses were conducted on anthills 1 and 2. Table 1 shows sieve analysis of soils. Anthill 1 had higher mass retained on $2.00 \mathrm{~mm}$

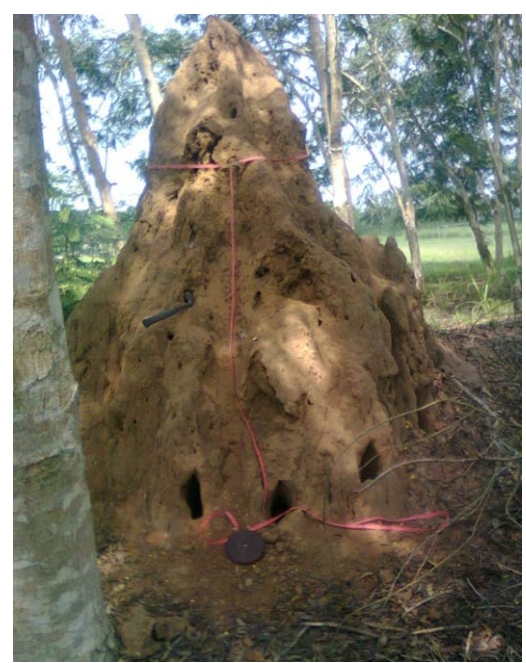

Figure 2. Anthill showing ventilation holes.

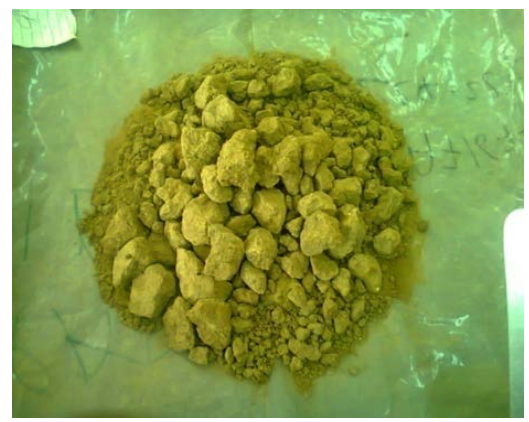

Figure 3. Coned brownish yellow soil from an anthill.

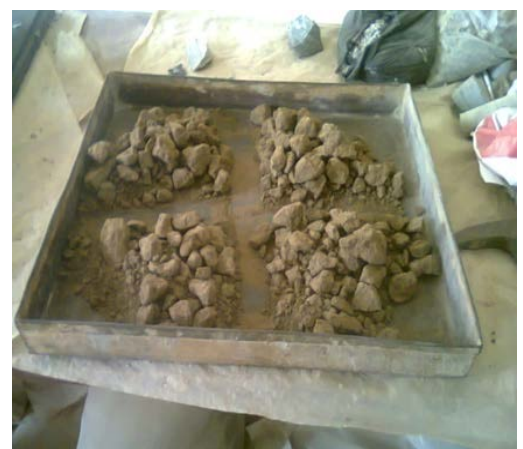

Figure 4. Quartered light brown soil from an anthill. 
Table 1. Sieve analysis of soil from Anthills at various positions $(\mathrm{A}=\mathrm{base}, \mathrm{B}=$ Middle and $\mathrm{C}=$ Top).

\begin{tabular}{cccccccccc}
\hline \multirow{2}{*}{$\begin{array}{c}\text { Sieve size } \\
(\mathrm{mm})\end{array}$} & \multicolumn{3}{c}{ Anthill 1 (g) } & \multicolumn{3}{c}{ Anthill 2 (g) } & \multicolumn{3}{c}{ Anthill 3 (g) } \\
\cline { 2 - 10 } & A & B & C & A & B & C & A & B & C \\
\hline 2.000 & 8.6 & 11.4 & 4.1 & 2.2 & 1.1 & 0.5 & 1.7 & 1.3 & 1.0 \\
1.180 & 33.6 & 37.3 & 31.3 & 15.5 & 13.6 & 11.5 & 11.1 & 11.8 & 11.5 \\
0.600 & 24.0 & 29.6 & 26.7 & 17.5 & 18.1 & 18.7 & 50.2 & 61.4 & 65.2 \\
0.425 & 15.6 & 16.7 & 17.5 & 10.8 & 11.8 & 11.4 & 74.9 & 77.5 & 84.8 \\
0.300 & 13.8 & 15.4 & 16.0 & 10.4 & 10.0 & 11.1 & 25.4 & 15.6 & 17.2 \\
0.212 & 16.3 & 18.2 & 19.2 & 12.5 & 12.4 & 13.5 & 33.5 & 22.6 & 34.0 \\
0.150 & 13.7 & 15.7 & 16.7 & 10.9 & 10.3 & 11.5 & 14.8 & 15.4 & 18.8 \\
$>\mathbf{0 . 0 7 5}$ & $\mathbf{1 5 1 . 5}$ & $\mathbf{1 7 9 . 1}$ & $\mathbf{1 6 8 . 1}$ & $\mathbf{1 0 7 . 7}$ & $\mathbf{1 0 9 . 6}$ & $\mathbf{1 1 8 . 0}$ & $\mathbf{2 4 1 . 1}$ & $\mathbf{2 3 1 . 4}$ & $\mathbf{2 7 6 . 6}$ \\
$<\mathbf{0 . 0 7 5}$ & $\mathbf{3 4 8 . 5}$ & $\mathbf{3 2 0 . 9}$ & $\mathbf{3 3 1 . 9}$ & $\mathbf{3 9 2 . 3}$ & $\mathbf{3 9 0 . 4}$ & $\mathbf{3 8 2 . 0}$ & $\mathbf{2 5 8 . 9}$ & $\mathbf{2 6 8 . 6}$ & $\mathbf{2 2 3 . 4}$ \\
\hline
\end{tabular}

sieve size ( $8.6 \mathrm{~g})$ followed by anthill 2 ( $2.2 \mathrm{~g})$ and then anthill 3 (1.7 g); total mass above $0.075 \mathrm{~mm}$ sieve size was higher in anthill 3 (231.4 - $276.6 \mathrm{~g})$, followed by anthill 1 (151.5 - $179.1 \mathrm{~g})$ and then anthill $2(107.7 \mathrm{~g}-118.0 \mathrm{~g})$; fines were higher in anthill 2 (392.3 - 382.0 g), followed by anthill 1 (320.9 - $348.5 \mathrm{~g})$ and least in anthill 3 (223.4 - $268.6 \mathrm{~g}$ ) (Table 1). For major oxides, $\mathrm{SiO}_{2}$ range from 51.70 60.24 wt. \%, $\mathrm{Al}_{2} \mathrm{O}_{3}(22.18$ - 28.88 wt. \%), total $\mathrm{FeO}$ (12.22 - 15.24 wt. \%), $\mathrm{MgO}$ (1.20 - 1.90 wt. \%) (Table 2). Graphs of mass against sieve sizes (over size and under size) were plotted for anthills 1 to 3 (Figures 5-7). Histograms of mass retained on sieve sizes were plotted against height in anthills, respectively (Figure 8 and Figure 9). $\mathrm{SiO}_{2}$ (wt. \%) was plotted against $\mathrm{Al}_{2} \mathrm{O}_{3}$ (wt. \%), total $\mathrm{FeO}$ (wt. \%), $\mathrm{MnO}$ (wt. \%), and $\mathrm{K}_{2} \mathrm{O}$ (wt. \%) to determine their correlation and variation with height (as shown in Figures 10-13).

\section{Discussion}

Percentage of soil grain size from anthills which passed through sieve size 0.075 $\mathrm{mm}$ was more than the retained (Table 1). Thus, the fraction of fines was more than sand fraction in the clay used in molding the anthills. According to Anon. [11] the size of these termites from subterranean worker termites might be as short as $3.175 \mathrm{~mm}$ to up to $9.525 \mathrm{~mm}$ in length, soldiers might be slightly longer, while the reproductive queens and kings could be over $19.050 \mathrm{~mm}$. Hence such small creatures which carried grain sizes up to $2 \mathrm{~mm}$ must have used much effort or team work to offset gravity on the load. Yet in their effort to build the mighty structures, relatively smaller masses of grains could have been used for the construction at higher parts of the anthill/mound. Figure 8 shows decrease in mass of sand size grains with increasing termite mound height whilst for finer grains, mass increased higher up the termite mound.

$\mathrm{SiO}_{2}$ (wt. \%) decreased higher up of anthill 1 but increased with increasing height in anthill 2 (Figure 10). Surprisingly, $\mathrm{Al}_{2} \mathrm{O}_{3}$ content generally increased higher up the anthills. Total $\mathrm{FeO}$ increased higher up anthill 1, but decreased 
Table 2. XRF analysis of soil from anthills at various positions $(\mathrm{A}=$ base, $\mathrm{B}=$ Middle and $\mathrm{C}=\mathrm{Top})$.

\begin{tabular}{|c|c|c|c|c|c|c|}
\hline $\begin{array}{l}\text { Major Oxide } \\
\text { (wt. \%) }\end{array}$ & $1 \mathrm{~A}$ & $1 \mathrm{~B}$ & $1 \mathrm{C}$ & $2 \mathrm{~A}$ & $2 \mathrm{~B}$ & $2 \mathrm{C}$ \\
\hline $\mathrm{SiO}_{2}$ & 56.08 & 51.70 & 51.88 & 54.30 & 56.65 & 60.24 \\
\hline $\mathrm{TiO}_{2}$ & 1.22 & 1.20 & 1.18 & 1.30 & 1.38 & 1.38 \\
\hline $\mathrm{Al}_{2} \mathrm{O}_{3}$ & 27.29 & 27.79 & 28.88 & 22.18 & 23.18 & 23.72 \\
\hline $\mathrm{FeO}_{\mathrm{T}}$ & 14.35 & 14.92 & 15.24 & 12.42 & 12.24 & 12.22 \\
\hline $\mathrm{MnO}$ & 0.09 & 0.09 & 0.09 & 0.09 & 0.08 & 0.08 \\
\hline $\mathrm{MgO}$ & 1.58 & 1.50 & 1.50 & 1.20 & 1.90 & 1.78 \\
\hline $\mathrm{CaO}$ & 0.34 & 0.25 & 0.20 & 0.25 & 0.24 & 0.23 \\
\hline $\mathrm{Na}_{2} \mathrm{O}$ & 1.27 & 0.92 & 1.06 & 0.95 & 1.17 & 1.19 \\
\hline $\mathrm{K}_{2} \mathrm{O}$ & 0.61 & 0.40 & 0.34 & 0.34 & 0.38 & 0.39 \\
\hline $\mathrm{P}_{2} \mathrm{O}_{5}$ & 0.09 & 0.09 & 0.08 & 0.07 & 0.06 & 0.07 \\
\hline $\mathrm{SO}_{3}$ & 0.08 & 0.08 & 0.07 & 0.08 & 0.08 & 0.07 \\
\hline Total & 103.00 & 98.93 & 100.52 & 93.17 & 97.37 & 101.38 \\
\hline \multicolumn{7}{|c|}{ Trace Elements (ppm) } \\
\hline $\mathrm{Ti}$ & 0.73 & 0.72 & 0.71 & 0.78 & 0.83 & 0.82 \\
\hline $\mathrm{V}$ & 0.02 & 0.02 & 0.02 & 0.02 & 0.02 & 0.02 \\
\hline $\mathrm{Cr}$ & 0.03 & 0.04 & 0.03 & 0.04 & 0.03 & 0.02 \\
\hline Co & 63.00 & 44.00 & 70.00 & 72.00 & 102.00 & 63.00 \\
\hline $\mathrm{Ni}$ & 40.80 & 40.10 & 41.80 & 33.80 & 30.20 & 33.90 \\
\hline $\mathrm{Cu}$ & 46.00 & 42.00 & 45.40 & 34.70 & 33.70 & 34.40 \\
\hline $\mathrm{Zn}$ & 45.00 & 42.50 & 45.70 & 43.40 & 42.20 & 38.90 \\
\hline $\mathrm{Ga}$ & 22.30 & 22.10 & 24.00 & 20.70 & 20.30 & 20.30 \\
\hline Ge & 2.10 & 2.10 & 2.20 & 0.70 & 1.70 & 1.40 \\
\hline As & 10.40 & 11.40 & 11.20 & 9.50 & 11.60 & 10.20 \\
\hline $\mathrm{Br}$ & 0.90 & $<0.3$ & $<0.3$ & $<0.4$ & $<0.3$ & $<0.3$ \\
\hline $\mathrm{Rb}$ & 18.00 & 12.50 & 12.30 & 13.30 & 11.20 & 12.10 \\
\hline $\mathrm{Sr}$ & 41.10 & 29.80 & 23.30 & 26.80 & 22.90 & 22.70 \\
\hline $\mathrm{Y}$ & 0.90 & 1.20 & 0.90 & 0.90 & 1.60 & 0.80 \\
\hline $\mathrm{Zr}$ & 343.00 & 304.00 & 272.00 & 346.00 & 366.00 & 342.00 \\
\hline $\mathrm{Nb}$ & 18.00 & 18.60 & 14.60 & 23.50 & 21.60 & 21.60 \\
\hline Mo & 5.60 & $<4.4$ & $<6.0$ & 3.80 & 10.50 & $<4.7$ \\
\hline I & 53.00 & 54.30 & 54.50 & 44.70 & 36.90 & 37.00 \\
\hline Cs & 9.50 & $<9.30$ & $<9.40$ & $<9.90$ & $<9.70$ & 15.50 \\
\hline $\mathrm{Ba}$ & 263.50 & 177.70 & 146.20 & 176.00 & 183.80 & 168.20 \\
\hline $\mathrm{La}$ & $<19$ & 39.80 & 34.90 & 25.90 & $<20$ & $<19$ \\
\hline $\mathrm{Ce}$ & 80.00 & 56.00 & 48.00 & 68.00 & 65.00 & 56.00 \\
\hline
\end{tabular}




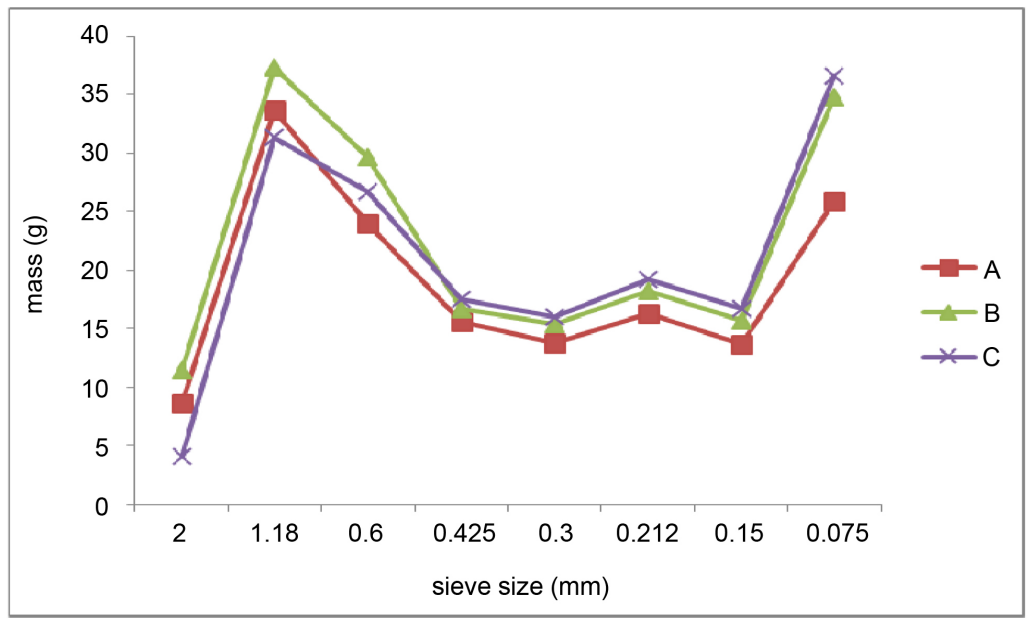

Figure 5. Graph of mass against sieve size for anthill 1.

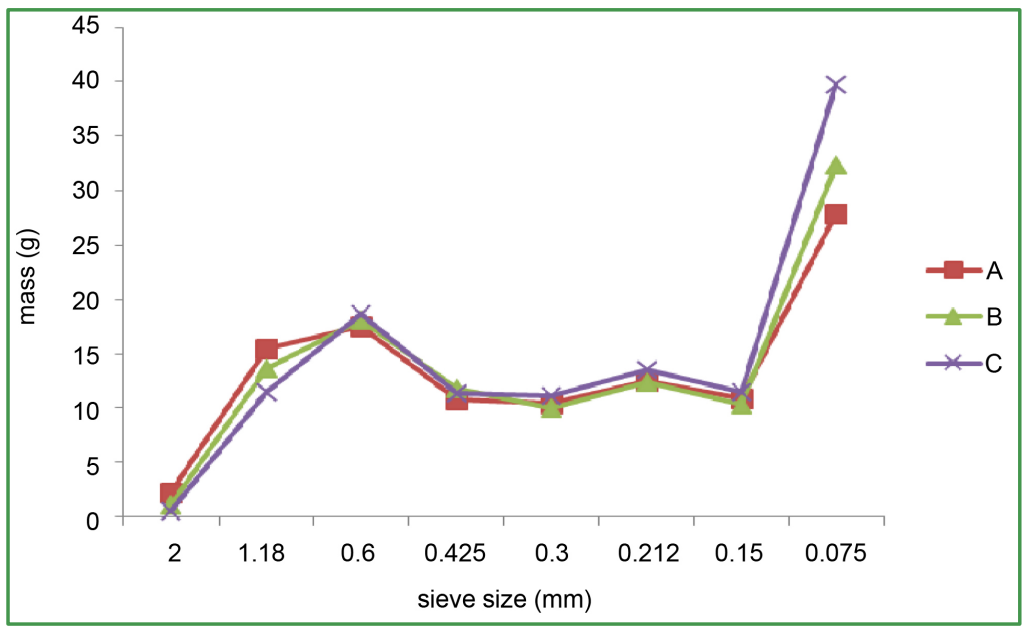

Figure 6. Graph of mass against sieve size for anthill 2.

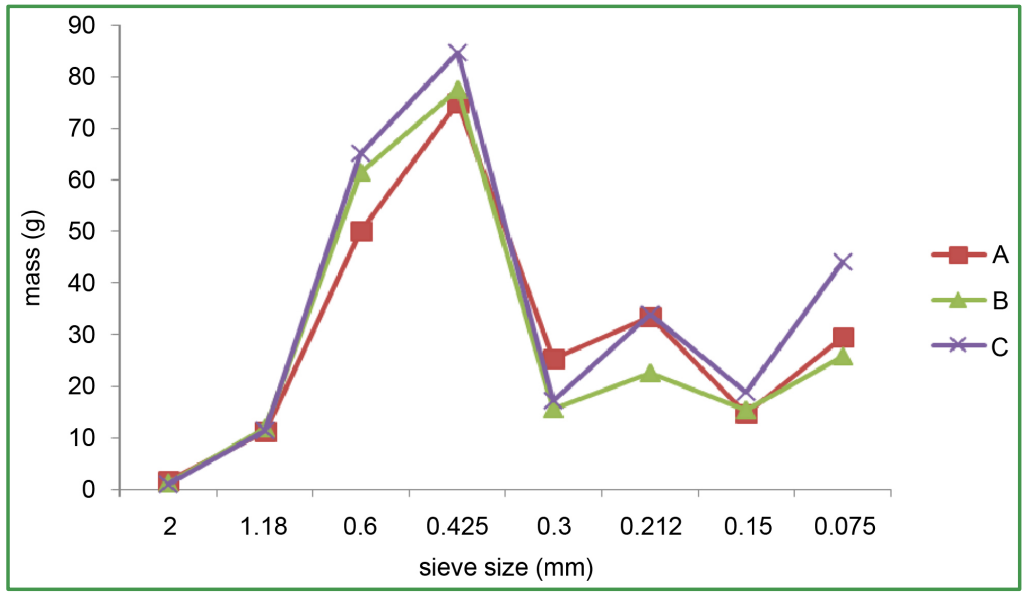

Figure 7. Graph of mass against sieve size for anthill 3.

steadily to the top of anthill 2. MnO was fairly constant in both anthills and almost homogeneous with height. $\mathrm{K}_{2} \mathrm{O}$ decreased with height in anthill 1 and 


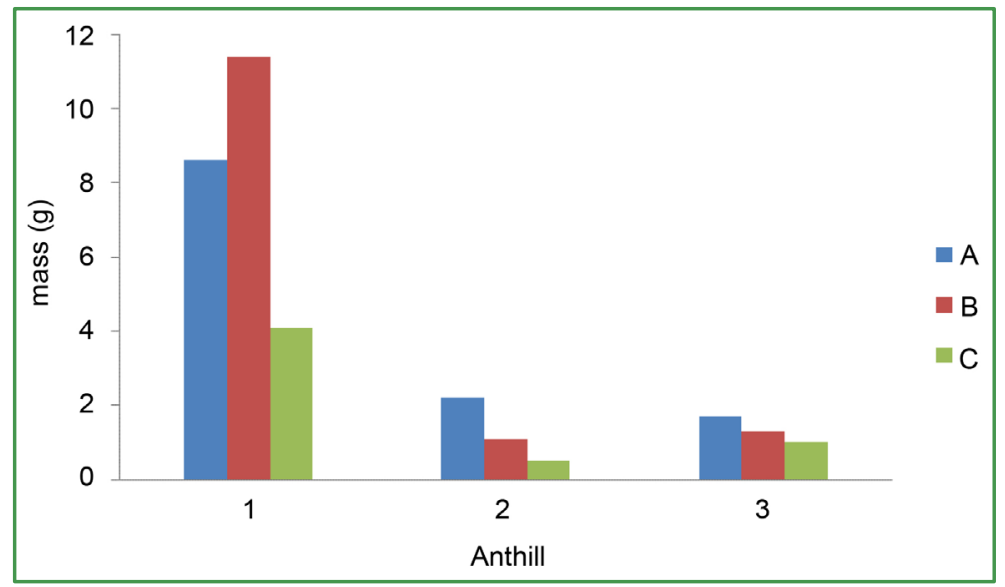

Figure 8. Graph of mass retained on $2 \mathrm{~mm}$ sieve against anthills at different spot heights.

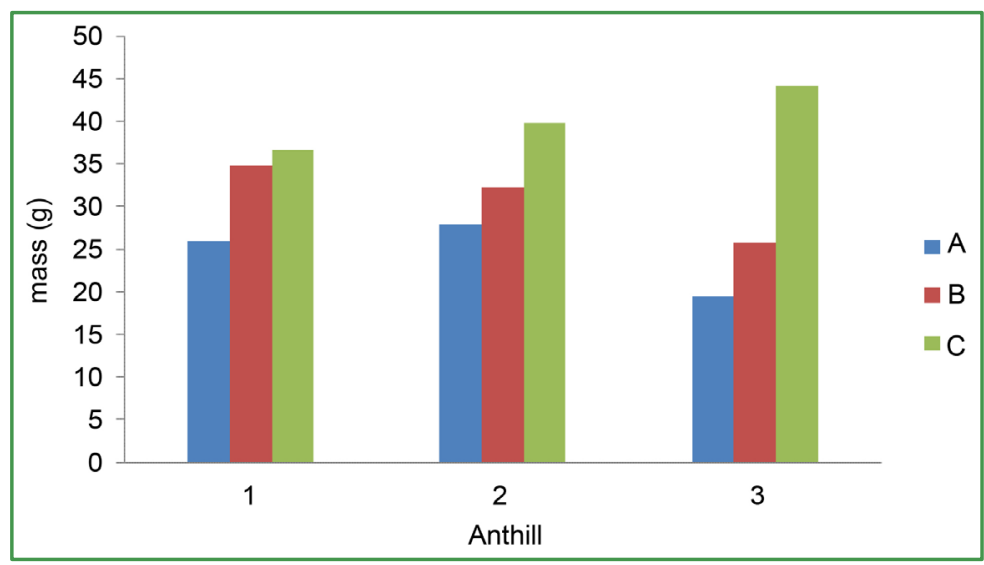

Figure 9. Graph of mass retained on $0.075 \mathrm{~mm}$ sieve against anthills at different spot heights.

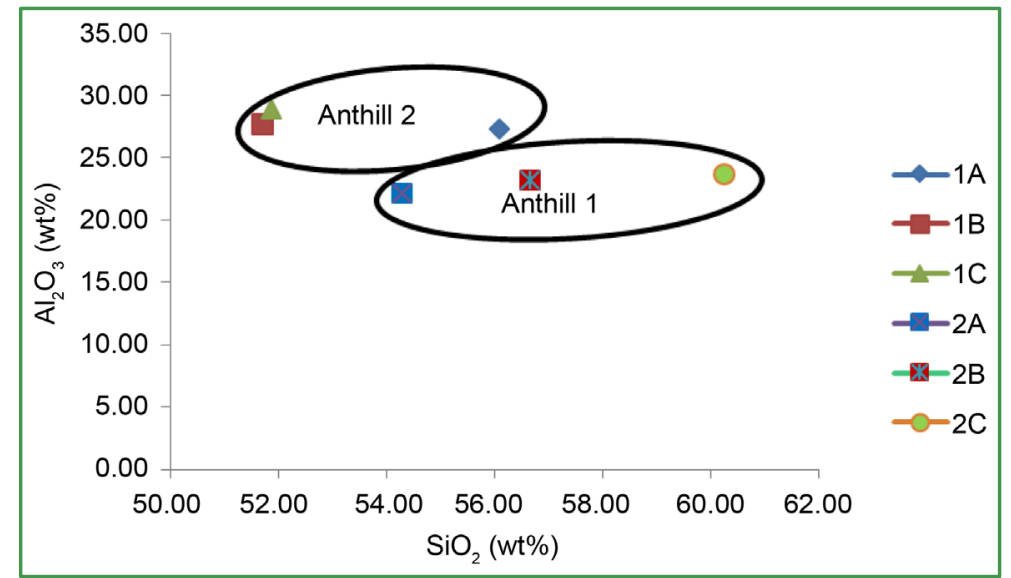

Figure 10. Binary plot of $\mathrm{SiO}_{2}$ against $\mathrm{Al}_{2} \mathrm{O}_{3}$ for anthills at different spot heights.

increased with height in anthill 2. The variations in the concentration of the major oxides suggest that soils used to construct the anthills were possibly derived 


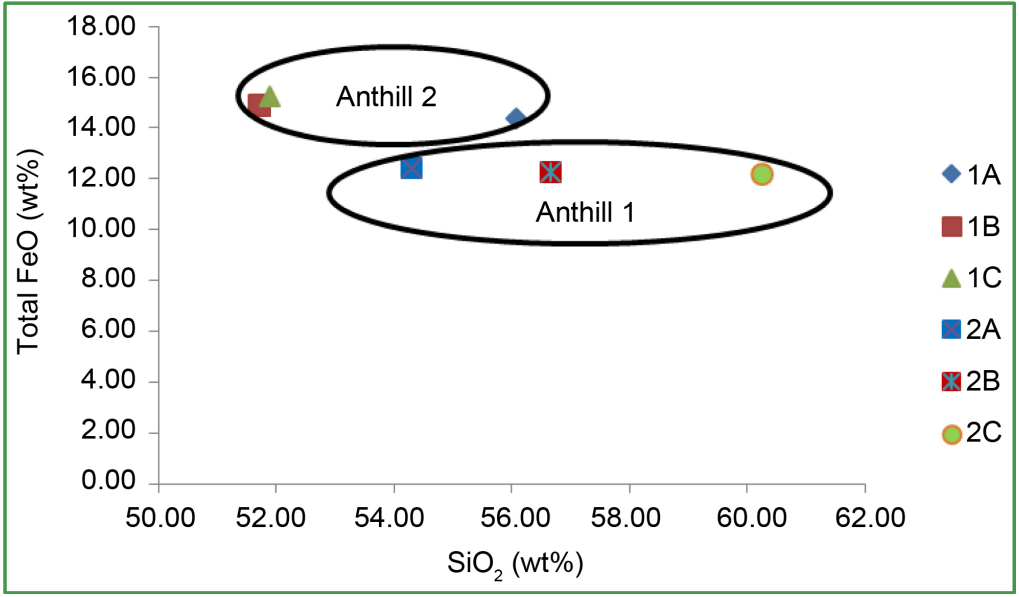

Figure 11. Binary plot of $\mathrm{SiO}_{2}$ against total $\mathrm{FeO}$ for anthills at different spot heights.

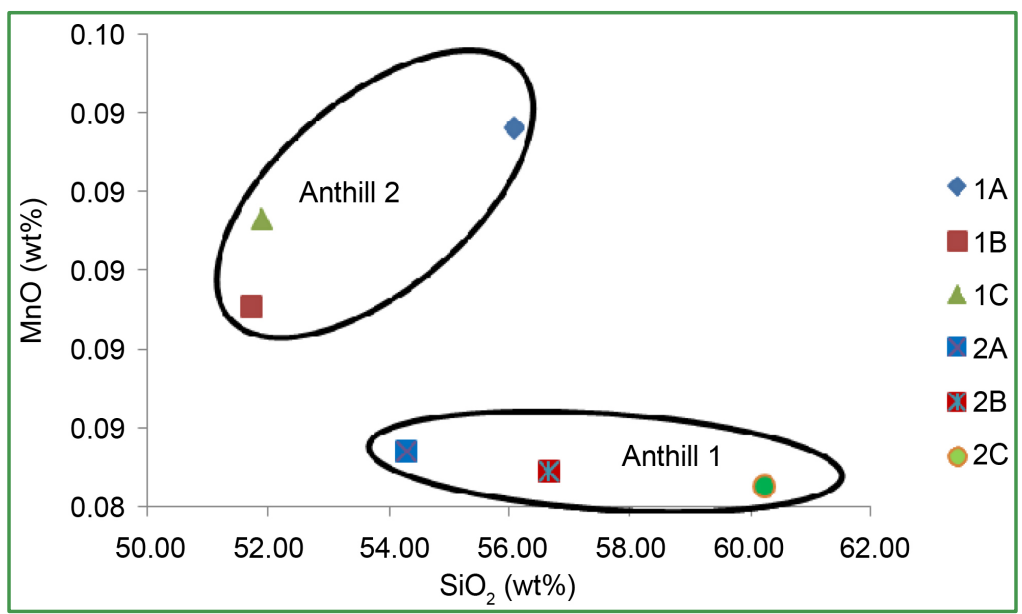

Figure 12. Binary plot of $\mathrm{SiO}_{2}$ against $\mathrm{MnO}$ for anthills at different spot heights.

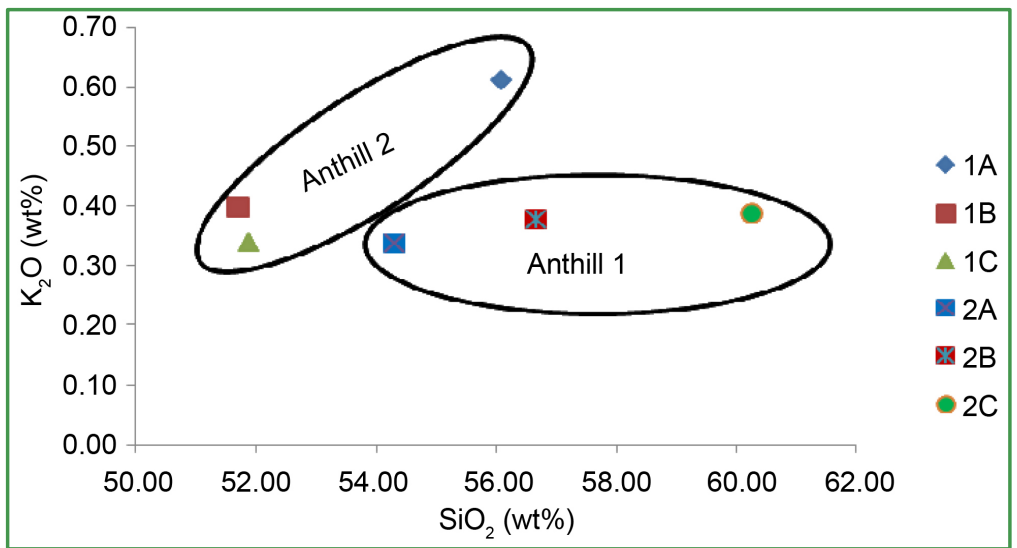

Figure 13. Binary plot of $\mathrm{SiO}_{2}$ against $\mathrm{K}_{2} \mathrm{O}$ for anthills at different spot heights.

from different rock types or there were differences in termite preference for clay richer in selective $\mathrm{SiO}_{2}$ or total $\mathrm{FeO}$. 


\section{Conclusions}

The anthills showed that the termites had similar building techniques. Soils for construction of anthills were mainly sand and clay of varied proportions. The variation in grain size differed from one locality to another and height on the anthill as more fines $(<0.075 \mathrm{~mm})$ were used in the construction of the upper parts.

$\mathrm{SiO}_{2}$ was positively correlated with total $\mathrm{FeO}, \mathrm{Al}_{2} \mathrm{O}_{3}, \mathrm{MnO}$, and $\mathrm{K}_{2} \mathrm{O}$. Whilst $\mathrm{SiO}_{2}$, total $\mathrm{FeO}$ and $\mathrm{Al}_{2} \mathrm{O}_{3}$ increased with height; there was a decrease in $\mathrm{K}_{2} \mathrm{O}$ with height of anthill. Major oxides were different in anthill 1 and 2 possibly due to differences in rock types from which these soils were derived. There could also be different types of termites involved in the construction process as different anthills exhibited clay richer in silica or total iron oxide. Hence during mineral prospecting, geochemical sampling and analysis of upper portions of anthills (where fine fractions usually occur) are recommended as these portions may yield valuable information of the geology of the area. Care should, however, be taken for uniformity of sample material in terms of colour, type and size of anthills.

\section{References}

[1] Hole, F.D. (1981) Effects of Animals on Soil. Geoderma, 25, 75-112. https://doi.org/10.1016/0016-7061(81)90008-2

[2] Lavelle, P., Bignell, D., Lepage, M., Wolters, V., Rogers, P., Ineson, P., Heal, O.W. and Dhillion, S. (1997) Soil Functions in Changing World: The Role of Invertebrate Ecosystem Engineers. European Journal of Soil Biology, 33, 159-193.

[3] Folgarait, P.J. (1998) Ant Biodiversity and Its Relationship to Ecosystem Functioning. A Review Biodiversity Conservation, 7, 1221-1244.

https://doi.org/10.1023/A:1008891901953

[4] Akinboboye, F.A.O. and Ogunfayo, I.K. (2012) Assessment of the Severity of $\mathrm{CO}_{2}$ Emission from Anthill Soils used as Replacement for Shale in Cement Manufacture. International Journal of Academic Research in Business and Social Sciences, 2, 145-149.

[5] West, W.F. (1965) Some Unconventional Ideas on Prospecting. Rhodesia Chamber of Mines Journal, 7, 40-42.

[6] Affam, M. and Arhin, E. (2005) Termite Mound-A Supplementary Geochemical Gold Sampling Medium in Complex Regolith Terrain. Ghana Mining Journal, 8, 10-15.

[7] Rao, K.S.P. and Raju, S.V. (1984) The Geochemical Analysis of Termite Mound as a Prospecting Tool for Tin Deposit in Bastaar, M.P.-A Preliminary Study. Proceedings of the Indian Academy of Sciences-Earth and Planetary Sciences, 93, 141-148.

[8] Anon (2013) Geology of Apam-Winneba. www.ghanadistrict.gov.gh

[9] Kesse, G.O. (1985) Rock and Mineral Resources of Ghana. A. A. Balkema Publishers, Rotterdam, 610.

[10] Leube, A., Hirdes, W., Mauer, R. and Kesse, G.O. (1990) The Early Proterozoic Birimian Supergroup of Ghana and Some Aspects of its Associated Gold Mineralisation. Precambrian Research, 46, 136-165. 
https://doi.org/10.1016/0301-9268(90)90070-7

[11] Anon (2012) How Big Are Termites?

http://www.termitesgonewild.com/termite-pictures/how-big-are-termites

Submit or recommend next manuscript to SCIRP and we will provide best service for you:

Accepting pre-submission inquiries through Email, Facebook, LinkedIn, Twitter, etc. A wide selection of journals (inclusive of 9 subjects, more than 200 journals)

Providing 24-hour high-quality service

User-friendly online submission system

Fair and swift peer-review system

Efficient typesetting and proofreading procedure

Display of the result of downloads and visits, as well as the number of cited articles Maximum dissemination of your research work

Submit your manuscript at: http://papersubmission.scirp.org/

Or contact gep@scirp.org 